\title{
Patent office under fire over consultation
}

Munich. The European Patent Office (EPO) has come under fire from groups opposed to the patenting of genes and living organisms for declining to consult them over draft proposals, discussed at a forum in Munich last week, on how the European patent system could operate more effectively.

Four months ago, the EPO distributed to selected organizations a document drawn up by its administrative council, a body made up of representatives - usually the president of the national patent office - from each country that has signed the European Patent Convention.

The consultation document analysed, in particular, two major problems that the EPO faces. The main thrust concerned the high cost of European patents (see Nature 371, 371; 1994), but the public controversy over gene patenting was also put up for discussion.

But the EPO administrative council decided to restrict the hearing to groups concerned professionally with patents primarily patent lawyers and representatives of industry. The European Commission, which is developing a new European Union patent, was also represented.

This move has stimulated widespread criticism from public interest groups concerned with patent issues. Sue Mayer, for example, a member of Greenpeace who has been actively engaged on topics such as the patenting of the Harvard Oncomouse and herbicide-resistant plants, says that it was "foolish to restrict the debate, when the EPO should be trying to understand public concern [about patenting of life forms]".

Mayer and others have been particularly critical of the EPO document for claiming that attitudes towards patenting medical processes have recently changed, and that "a majority of EPO users would be in favour of scrapping" the current exclusion from patentability of plant or animal varieties. This is enshrined in an ambiguous clause of the 1973 European Patent Convention.

David Shapiro, executive secretary of the London-based Nuffield Council on Bioethics, points out that this statement was presented with no supporting evidence and appears to conflict with the general mood in the European Parliament in its vote opposing gene patents earlier this year (see Nature 374, 103; 1995). Shapiro and Meyer both claim that statements such as those in the EPO document - which was admittedly drawn up before the parliamentary vote merely indicate that the EPO administrative council is out of touch with public opinion.

Shapiro says he heard about the document only indirectly, and was invited by telephone to attend the hearing only two working days before it opened. He accepts the appropriateness of inviting patent lawyers and innovation groups to the hear-

\section{How the mouse's tale began life in India}

New Delhi. Genetic studies of wild Indian mice have led to a discovery that the house mouse, Mus musculus, originated in northern India. The finding has raised for the first time the prospect of inbred Indian strains being used as models by biologists.

A special animal facility at the

Geographical ranges of the subspecies of Mus. musculus

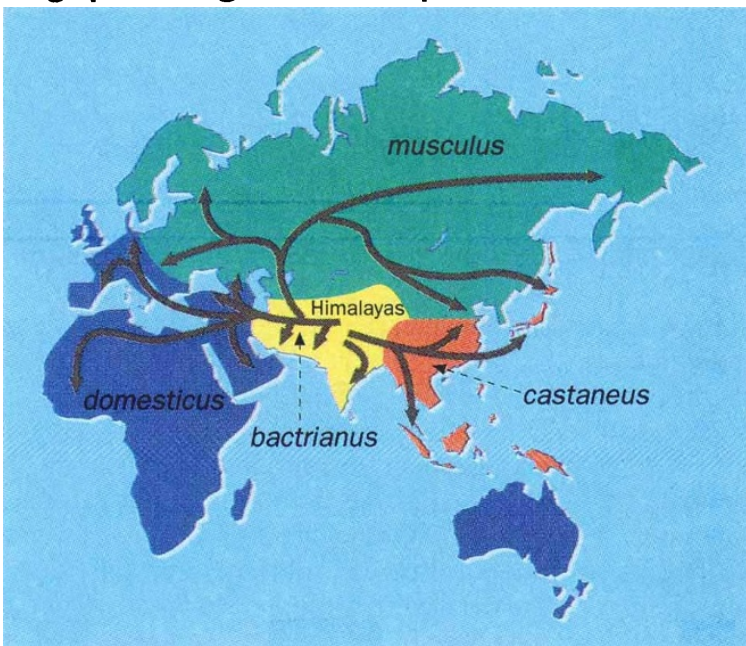

ing, which was primarily concerned with technical matters such as the high costs of patents. "But in matters of public interest it will not do to claim that you have had a public meeting when so many groups were excluded," he says.

Gerald Weiss, who heads the secretariat of the administrative council, defends the council's organization of the hearing, saying that the intention was primarily to gain input from user groups on ways in which patent costs could be reduced, and not to consider the patentability of biotechnology products.

He also says that the document was circulated among 250 journalists, though he admits that an invitation to attend the hearing was extended only to one journalist Tom Wilkie, science editor of the Independent newspaper in London, who submitted a written response. But leading journalists in Germany say they have no recollection of having received the document, and that they would have been interested to attend the meeting if they had been invited.

The strong representation of national patent offices on the administrative council is felt by some to have made it impossible for the EPO to tackle another factor contributing to the high cost of patenting through the EPO, namely that half of the fees paid to renew patent protection in designated countries remains with the patent office in those countries (see Nature 371, 371; 1994).

Many EPO staff members consider this an unfair subsidy of national patent offices, to the detriment of the EPO. Yet the administrative council is unanimous that the formula for distributing the fees should not be changed.

The EPO's apparent conservatism could be shaken up by the European Commission. The commission has been developing for a number of years progress on legislating for a community patent that would be valid in all 15 member states (which contrasts with the EPO patent which is valid only in countries designated by the patent holder).

Progress on this has until now been slow. Only seven member states have so far ratified the 1975 Community Patent Convention, and a diplomatic conference held in 1992 to find ways of speeding its enforcement was unsuccessful, primarily because of fears that the high costs involved in providing translations of applications into all EU languages would render the community patent unused.

Also, the commission is coming to the end of a major consultative phase on its failed directive on patenting of biotechnological products and will decide within the next few weeks if a revision will be put to the European Union Council of Ministers and the European Parliament Alison Abbott 